\title{
Jugular Foramen Meningioma
}

National Cancer Institute

\section{Source}

National Cancer Institute. Jugular Foramen Meningioma. NCI Thesaurus. Code C5293.

A meningioma that affects the jugular foramen. 